\title{
Development of Black Pepper Rotary Drum Dryer System
}

\section{Ana Sakura Zainal Abidin ${ }^{1 *}$, Mohamad Zulhatta Kifli ${ }^{1}$, Annisa Jamali ${ }^{1}$, Rasli Muslimen', Raudhah Ahmadi ${ }^{2}$}

\author{
${ }^{1}$ Department of Mechanical \& Manufacturing Engineering, \\ Universiti Malaysia Sarawak, Kota Samarahan, 94300, MALAYSIA \\ ${ }^{2}$ Department of Civil Engineering, \\ Universiti Malaysia Sarawak, Kota Samarahan, 94300, MALAYSIA \\ *Corresponding Author
}

DOI: https://doi.org/10.30880/ijie.2020.12.07.002

Received 23 March 2020; Accepted 3 August 2020; Available online 30 August 2020

\begin{abstract}
Rotary drum dryer has been identified as hygienic and practical method to dry black pepper. The quality of black pepper is defined based on the chemical properties and moisture content. This research aims to develop a control system for black pepper rotary drum dryer. The dried pepper should meet the specific $12 \%$ moisture content while the heating temperature must be kept below $55^{\circ} \mathrm{C}$. The requirement of $12 \%$ moisture content is equivalent to $30 \%$ of the remaining weight of the pepper (final weight). The developed system uses Arduino Mega 2560 REV board as a microcontroller. A type K thermocouple with MAX6675 thermocouple amplifier and S-type load cells (TAS501) with HX711 load cell amplifier are used as input sensor to microcontroller. The system keeps measuring the current weight until it hit the targeted final weight. Two set of experiments that are using $500 \mathrm{~g}$ and $1500 \mathrm{~g}$ of pre-treated pepper were conducted to verify the system. As a result, the dryer was successful to work within the desired temperature and it stop operating just after the samples reached $12 \%$ of the moisture content. The finding has proven a shorten of drying time from 4 to 7 days when using the traditional method to the current $3-5$ hours only when using the developed system. Hence, this is an improved method achieved to a quick drying of the black pepper.
\end{abstract}

Keywords: black pepper, rotary drum dryer, drying process, moisture content, pre-treatment

\section{Introduction}

The cultivation of pepper in Malaysia has started since 1856 and in the early 1900s, the plantation of pepper gets more extensive [1]. As shown in Fig. 1, Malaysia annual pepper export is increasing especially black pepper. The export value for black pepper is more than double of white pepper. In 2016, Malaysia ranks as the fifth largest pepper producer in the world [2]. Due to the market demand, farmers preferred to produce black pepper rather than white pepper [3].

The black pepper is produced from the almost-matured peppercorn or greenish looked. In order to ensure the black peppers are safe for storage and transportation, the peppercorn needs to go through an intensive drying process called dehydration. The peppercorn is usually dried under the sun. During the drying process, browning enzyme settles in and the phenolic compounds are then oxidized by atmospheric oxygen under the catalytic influence of the enzyme phenolase and eventually turning into green colour of matured pepper pigment to black [5], [6]. 